\title{
KARAKTERISTIK KIMIA PADA PEMBUATAN MI SAGU (METROXYLON SAGU) KERING
}

\section{CHEMICAL CHARACTERISTIC ON MAKING OF DRIED SAGO (METROXYLON SAGU) NOODLE}

\author{
Adnan Engelen $^{a}$, Sugiyono ${ }^{b}$, Slamet Budijanto ${ }^{b}$
}

aPoliteknik Gorontalo; Provinsi Gorontalo, Kode Pos 96583.

bInstitut Pertanian Bogor; Jalan Raya Darmaga, Bogor-16680

Korespodensi: Adnan Engelen, Email: adnanengelen@poligon.ac.id

\begin{abstract}
The wheat which is consumed in Indonesia is imported from abroad. This is a problem. To reduce the dependency of imported wheat, it is a necessity to use local products with local raw materials. One of them is sago. To create noodle with the local product can use sago as the raw material. The aim of this research was to make dried sago noodle. Sago noodle was created through a process using twin screw extruder with the replenishment of GMS (Glycerol Monostearate) and ISP (Isolated Soybean Protein). Two stages were conducted in this study: 1) making of dried sago noodle, 2) characterization of chemical, colour and organoleptic/sensory properties of dried sago noodle. Dried sago noodle produced chemical compositions, ie water $(10: 32 \%)$, ash $(0.20 \%)$, protein $(2.63 \%)$, fat $(12: 21 \%)$, carbohydrates (86.63\%), and the value of color ( $\mathrm{L}=34.70, \mathrm{a}=2.56, \mathrm{~b}=6.19)$. There was no significant difference from the result of t-test between dried sago noodle and flour noodle on the parameters of hardness, adhesiveness, elongation and overall.
\end{abstract}

Keywords : GMS (Glycerol monostearate), ISP (Isolated soybean protein), sago, noodle

\begin{abstract}
ABSTRAK
Gandum yang dikonsumsi di Indonesia diimpor dari luar negeri. Untuk meminimalisir impor gandum dibutuhkanbahan-bahan olahan lokal dan digunakan menjadi produk lokal. Salah satu produk lokal yang berasal dari bahan baku lokal adalah sagu. Pemanfaatan sagu dapat digunakan sebagai bahan baku untuk membuat mi. Penelitian ini bertujuan untuk memproduksi mi sagu kering. Sagu mi dibuat melalui suatu proses menggunakan twin screw extruder dengan menambahkan emulsifier berupa GMS (Gliserolmonostearat) dan ISP (Isolated Soybean Protein). Dua tahapan yang dilakukan pada penelitian ini : 1) pembuatan mi sagu kering, 2) karakterisasi kimia, warna dan sifat sensori misagu kering. Mi sagu kering menghasilkan komponen kimia antara lain air (10.32\%), abu $(0.20 \%)$, protein $(2.63 \%)$, lemak (0.21\%), karbohidrat (86.63\%), dan nilai warna $(L=34.70, a=2.56, b=6.19)$. Hasil penelitian dengan menggunakan uji t-test menunjukkan bahwa tidak terdapat perbedaan signifikan antara mi sagu kering dan mi terigu pada parameter kekerasan, kelengketan, elongasi dan overall.
\end{abstract}

Kata Kunci : GMS (Gliserolmonostearat), ISP (Isolatedsoybeanprotein), sagu, mi

Engelen, A. Sugiyono. Slamet, B. 2017. Karakteristik Kimia pada Pembuatan Mi Sagu (Metroxylon sagu) Kering. Jurnal Agroindustri Halal 3(1): 001 - 009. 


\section{PENDAHULUAN}

Pati sagu adalah salah satu olahan sagu sumber karbohidrat (Mohamed et al. 2008; Budijanto dan Yulianti 2012; Ruku S 2009). Dalam rangka diversifikasi pangan maka sagu perlu diperhatikan, karena manfaat potensinya yang besar tetapi belum dimanfaatkan secara maksimal. Upaya pengembangan produk berbasis sagu dapat menjadi harapan untukmencegah keinginan mengkonsumsi tepung terigu/gandum secara berlebihan dalam pembuatan mi. Menurut Ditjenbun Kementan (2013) dan Bintoro (2016) bahwa lahan sagu dunia seluas 2.5 juta $\mathrm{Ha}$, di Indonesia seluas 1.25 juta Ha (50\% atau $1 / 2$ dari lahan sagu dunia), dan dari luas tersebut 1.2 juta Ha terdapat di Papua dan Papua Barat. Wiraguna et al. (2009); Syakir M dan Karmawati E (2013) melaporkan bahwa pemanfaatan pati sagu juga untuk berbagai macam keperluan, misalnya bahan bakar "biofuel" (etanol), bahan dasarpelezat masakan (monosodium glutamat), bahan dasar plastik ramah lingkungan yang dapat terurai dalam tanah. Sementara itu, pakan ternak dapat dijadikan sebagai limbah pengolahan sagu sebagai bentuk pemanfaatan limbah.

Menurut Tan et al. (2009), mi berbahan gandum berbeda dengan mi berbahan pati dari segi karakteristik. Hal ini disebabkan karena satu atau dua perlakuan panas dialami oleh mi pati selama proses. Perlakuan panas dapat dilakukan melalui proses perebusan yang meyebabkan terjadinya terjadinya gelatinisasi pati dan selanjutnya mengalami retrogradasi yang membentuk mi pati. Tiga metode yaitu dropping, cutting, dan extrudingmerupakan pengelompokan teknologi pengolahan mi pati (Tan et al. 2009). Teknologi proses pembuatan $\mathrm{mi}$ pati yang tradisional termasuk dalam metode dropping dan cutting, sedangkan teknologi proses pembuatan mi pati yang modern termasuk metode extruding. Mi pati yang efisien dan prosedur yang lebih sederhanatanpa mempersiapkan pasta pati secara terpisah dapat dihasilkan dari metode extruding. Metode ini dapat menghasilkan mi pati yang transparan dan tidak mudah mengalami kerusakan akibat pemasakan.

Mutu produk yang baikyang dapat dihasilkan dari salah satu jenis extruder adalah jenis extruder pemasak-pencetak (cooking-formingextruder). Extruder pemasak-pencetak memproduksi mi pati yang memiliki cookingloss yang rendah yaitu 4,20\% (Marti et al. 2011), 7,10\% (Charutigon et al. 2008), 4,56\% (Muhandri et al. 2011) dan 4,80\% (Subarna et al. 2012).

Hingga sekarang ini telah dilakukan penelitian produksi mi pati dari karbohidrat seperti jagung, kentang, singkong dan sagu. Namun, penelitian masih diperlukan untuk mendapatkan nilai nutrisi yang baik dari produksi mi pati. Berdasarkan penelitian Takahashi et al. (1986) penambahan ISP (IsolatedSoybeanProtein) sebanyak 5\% dapat meningkatkan elongasi, menurunkan kelengketan, dan kelarutan pada mi berbahan dasar pati kentang dan pati kacang hijau (Tan et al. 2009).

Berdasarkan studi Kaur et al. (2005) bahwa penambahan GMS (Glyserol Monostearate) sebanyak $1 \%$ dapat menurunkan cookinglosspada mi pati jagung dan mi pati kentang. Penelitian mengenai kandungan proximat pada produksi mi dari pati sagu dengan penambahan ISP dan GMS belum banyak dilakukan. Maka dari itu, penelitian ini dilakukan untuk mengetahui kandungan proximat, warna dan sensori pada produksi mi sagu kering.

\section{MATERI DAN METODE}

Penelitian ini menggunakan bahan utama antara lain glycerolmonostearate (GMS) diperoleh dari PT Lautan Luas, Jakarta, isolatedsoybeanprotein (ISP) dan pati sagu hasil ekstraksi batang tanaman 
sagu (Metroxylonsagu) diperoleh dariPT.Bina Sago Lestari, Jakarta. Alat-alat yang dipakaidalam penelitian ini antara laindough mixer, timbangan, twin screw extruder(ekstruder ulir ganda)(Berto BEXDS-2256), pengering rak (tray drier), desikator berisi bahan pengering, oven, penangas, chromameter (CR 300 Minolta, USA) dan alat-alat pendukung lainnya. Dua tahapan yang dilakukan pada penelitian ini yaitu 1) proses produksi mi sagu kering, 2) karakterisasi sifat kimia, warna dan sensori mi sagu kering.

\section{Proses produksi mi sagu kering}

Trialand error dilakukan pada proses produksi mi sagu kering yang terdiri atas tiga tahapan, yaitu 1) pemilihan rangesuhu proses ekstruderdan kadar air adonan, 2) pemilihan suhu dan waktu pengeringan pada alat pengering rak (tray drier), dan 3) pemilihan konsentrasi ISP dan GMS. Range suhu proses ekstruderpada tahap pertama adalah $60,65,80$ dan $85^{\circ} \mathrm{C}$, sedangkan kadar air yang dipakai adalah 40, 50, 60 dan $70 \%$ dari berat bahan pati sagu $(2 \mathrm{~kg})$. Batas maksimal dan minimum terhadap suhu proses pada ekstruder ulir ganda dan kadar air (ka) ditentukan pada tahap penetapan batas maksimal dan minimum yang bertujuan untuk memperoleh nilai kisaran maksimal dan minimum penggunaan suhu ekstruder dan kadar air (ka) sehingga mi dengan karakteristik fisik yang baik dapat dihasilkan.Mi pati sagu dengan karakteristik fisik yang dihasilkan dari ekstruder diperoleh dari pemilihan range suhu proses ekstruder dan kadar air adonan. Pada tahap ini mi yang diproduksi adalah $2 \mathrm{~kg}$ pati sagu yang ditambahkan dengan air sesuai perlakuan (40-70\%), setelah penambahan air dilakukan pengadukan dengan menggunakan dough mixer selama \pm 20 menit, setelah pengadukan adonan dituangkan ke dalam ekstruder dan dilakukan proses dengan suhu sesuai perlakuan $\left(60-85^{\circ} \mathrm{C}\right)$ untuk menghasilkan mi pati sagu. Mi sagu kering yang diproses dapat dilihat pada gambar dibawah ini (Gambar 1).

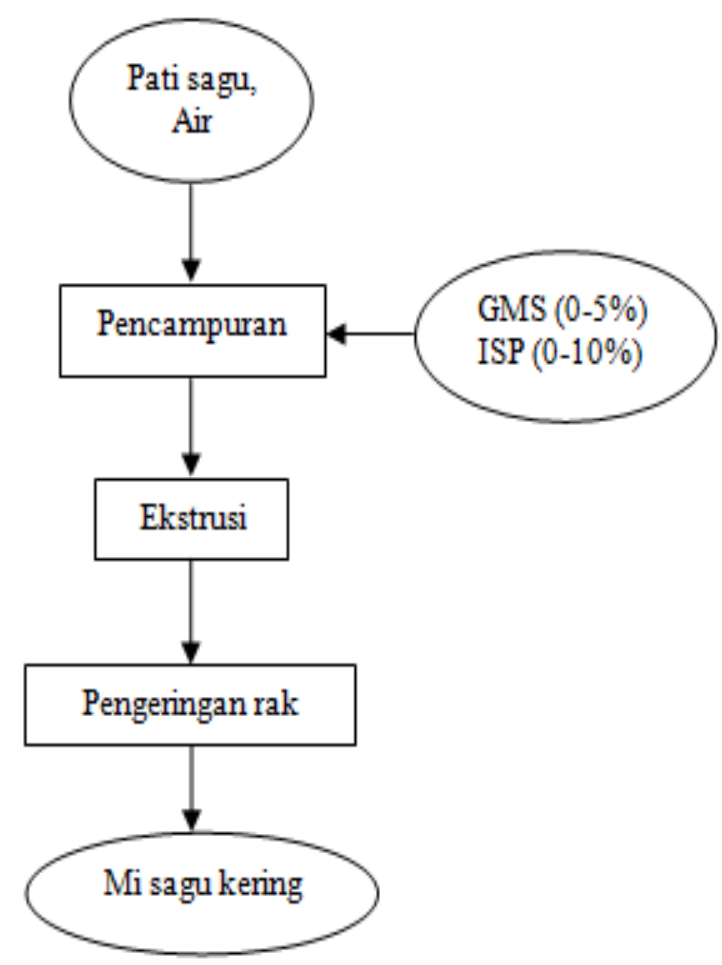

Gambar 1.Proses produksi misagu kering

Tahap kedua bertujuan untuk memperoleh range suhu pengeringan mi pati sagu yang diperoleh pada tahap pertama. Pengeringan suhu yang dipakai menggunakan suhu 40,50 dan $60^{\circ} \mathrm{C}$. Mi sagu kering dengan karakteristik fisik yang baik dengan lama pengeringan terkecil adalah hasil dari suhu pengeringan terpilih. Alat pengering rak digunakan untuk melakukan proses pengeringan.

Tahap ketiga adalah penentuan kisaran konsentrasi GMS dan ISP. Penentuan range dilakukan berdasarkan riset Takahashi et al. (1986) yang menggunakan mi berbahan dasar pati kentang dan pati kacang hijau dengan penambahan ISP sebanyak 5\% dan penelitian Kaur et al. (2005) yang menggunakan mi pati jagung dan mi pati kentang dengan penambahan GMS sebanyak 1\%. Berdasarkan riset tersebut maka penggunaan GMS dan ISP adalah 
pada range konsentrasi $(0-5 \%)$ pada GMS dan $(0-10 \%)$ pada ISP.

\section{Karakterisasi Sifat Kimia, Warna dan Sensori Mi Sagu Kering}

Mi sagu kering yang diperoleh selanjutnya dikarakterisasi sifat kimia, warna dan sensorinya. Karakterisasi sifat kimia yang dilakukan adalah analisis proksimat. Karakterisasi warna berdasarkan analisis warna notasi Hunter $(\mathrm{L}, \mathrm{a}, \mathrm{b})$ dengan menggunakan chromameter. Mi sagu kering dan mi terigu yang beredar di pasaran dikarakterisasi secara sensori dengan uji kesukaan atau uji rating hedonik.

\section{Analisis Kadar Protein (SNI-01-2891- 1992)}

Sampel sebanyak 0,5 g dituangkan ke dalam labu kjeldahl $100 \mathrm{ml}$. Lalu ditambahkan $2 \mathrm{~g}$ campuran selen (Campuran 2,5 g serbuk SeO2, $100 \mathrm{~g} \mathrm{~K}_{2} \mathrm{SO}_{4}$ dan $30 \mathrm{~g} \mathrm{CuSO}_{4} 5 \mathrm{H}_{2} \mathrm{O}$ ) dan $25 \mathrm{ml} \mathrm{H}_{2} \mathrm{SO}_{4}$ pekat. Setelah itu, untuk proses pemanasan digunakan pemanas listrik atau api pembakar sampai mendidih dan larutan menjadi jernih kehijau-hijauan $( \pm$ 2 jam). Kemudian didinginkan dan encerkan.

Setelah itu, dituangkan ke dalam labu ukur $100 \mathrm{ml}$. Pipet $5 \mathrm{ml}$ larutan dan tuangkan ke dalam alat penyuling dan tambahkan $5 \mathrm{ml} \quad \mathrm{NaOH} \quad 30 \quad \%$ dan penggunaan indikator PP dengan beberapa tetes. kemudian Disuling sekitar 10 menit. $10 \mathrm{ml}$ digunakan untuk larutan asam borat $2 \%$ yang telah dicampur indikator sebagai penampung. ujung pendingin dibilas dengan air suling kemudian titar dengan larutan HCI $0.01 \mathrm{~N}$. Kerjakan penetapan blanko.

Kadar Protein $=\frac{(\mathrm{V} 1-\mathrm{V} 2) \times \mathrm{N} \times 0,014 \mathrm{xfk} \times \mathrm{fp}}{\mathrm{W}}$

Ket. $\quad \mathrm{W}=$ bobot sampel

$\mathrm{V} 1$ = volume HCI 0,01 $\mathrm{N}$ yang dipergunakan penitaran contoh

$$
\begin{aligned}
\mathrm{V} 2= & \text { volume HCI yang } \\
& \text { dipergunakan penitaran } \\
& \text { blanko } \\
\mathrm{N}= & \text { normalitas } \mathrm{HCI} \\
\mathrm{Fk}= & \text { protein dari makanan } \\
& \text { secaraumum } 6,25 \\
\mathrm{fp}= & \text { faktor pengenceran }
\end{aligned}
$$

\section{Analisis Kadar Lemak (SNI-01-2891- 1992)}

Sampel ditimbang sebanyak 1-2 gram lalu ditambah $30 \mathrm{ml} \mathrm{HCl} 25 \%$ dan $20 \mathrm{ml}$ air. Sampel dipanaskan hingga mendidih selama 15 menit di ruang asam kemudian dalam keadaan dilakukan penyaringan dengan kertas saring. Selanjutnya, air panas digunakan dalam pencucian kertas saring hingga tidak asam lagi. Kertas saring berikut isinya dikeringkan pada suhu $80^{\circ} \mathrm{C}$. Selanjutnya, kertas saring dilipat dan analisis selanjutya adalah tahap ekstraksi.

Oven yang bersuhu $100-110^{\circ} \mathrm{C}$ selama 15 menit digunakan untuk mengeringkan labu lemak yang akan dipakai untuk mengekstraksi, kemudian selama 5 menit didinginkan dalam desikator, selanjutnya dilakukan penimbangan. Kertas saring yang berasal dari output hidrolisis sebelumnya, dimasukkan ke dalam selongsong kertas saring baru dan disumbat kapas pada sisi atas dan bawahnya, selanjutnya dimasukkan ke dalam alat ekstraksi yang telah berisi pelarut hexana. Sekitar 6 jam dilakukan refluks. Kemudian pelarut yang ada di dalam labu lemak di destilasi, selanjutnya pemanasan dalam oven bersuhu $105^{\circ} \mathrm{C}$ terhadap labu lemak yang berisi lemak hasil ekstraksi hingga beratnya konstan, kemudian desikator digunakan untuk pendinginan pada labu lemak yang keluar dari oven, dan dilakukan penimbangan sampai mendapatkan berat tetap/konstan. Kadar lemak yang dihitung menggunakan rumus

$$
\% \text { lemak }=\frac{W-W 1}{W 2} \times 100 \%(2)
$$


Ket. $\quad \mathrm{W}=$ bobot $\operatorname{contoh}(\mathrm{g})$

$\mathrm{W} 1=$ bobot lemak sebelum ekstraksi (g)

$\mathrm{W} 2$ = bobot labu lemak setelah ekstraksi (g)

\section{Analisis Kadar Abu (SNI-01-2891-1992)}

Metode drying ash digunakan untuk pengukuran kadar abu. 3 gram sampel ditimbang pada cawan yang sudah diketahui bobotnya. kemudiandi atas nyala pembakaran diarangkan dan selanjutnya penggunaan suhu $550^{\circ} \mathrm{C}$ didalam tanur dilakukan untuk proses pengabuan hingga sempurna. Setelah itu pendinginan dilakukan dalam desikator dan penimbangan hingga diperoleh bobot tetap/konstan. Kadar abu yang dihitung dibandingkan dengan berat abu dan berat sampel dikali $100 \%$.

Kadar Abu $(\% \mathrm{bb})=\frac{a-b}{c} \times 100 \%$

Ket. $\quad a=$ berat labu dan sampel akhir (g)

$\mathrm{b}=$ berat labu kosong $(\mathrm{g})$

$\mathrm{c}=$ berat sampel awal $(\mathrm{g})$

\section{Kadar Air (SNI-01-2891-1992)}

Oven yang bersuhu $105^{\circ} \mathrm{C}$ selama 15 menit digunakan untuk mengeringkan cawan aluminium lalu dilakukan pendinginan selama 5 menit dalam desikator atau sampai terasa tidak panas lagi. Kemudian penimbangan cawan dilakukan dan dicatat beratnya. Cawan kosong yang telah diketahui beratnya digunakan untuk meletakkan sampel dengan berat (1-2 gram). Oven yang bersuhu $105^{\circ} \mathrm{C}$ digunakan untuk mengeringkan cawan beserta isi (sampel). Pengeringan dilakukan sampai diperoleh bobot tetap/konstan. Setelah dikeringkan, dilakukan pendinginan terhadap cawan dan isinya yang berupa sampel di dalam desikator, kemudian dilakukan penimbangan berat akhir, dan dihitung kadar air (ka) dengan persamaan :

$$
\text { Kadar air }(\% \mathrm{bb})=\frac{(x-y)}{(x-a)} \times 100 \%
$$

$$
\text { Ket. } \begin{aligned}
\mathrm{x}= & \text { berat cawan dan sampel } \\
& \text { sebelum dikeringkan }(\mathrm{g}) \\
\mathrm{y}= & \text { berat cawan dan sampel setelah } \\
& \text { dikeringkan }(\mathrm{g}) \\
\mathrm{a}= & \text { berat cawan } \operatorname{kos} \lg \mathrm{g})
\end{aligned}
$$

\section{Kadar Karbohidrat (SNI-01-2891-1992)}

Pengukuran kadar karbohidrat total dalam sampel dihitung dengan menggunakan rumus (dalam \%) :

$$
\begin{gathered}
\% \text { karbohidrat }=100 \%-\% \text { (protein }+ \\
\text { lemak }+ \text { abu }+ \text { air })
\end{gathered}
$$

\section{Analisis Warna dengan Chromamater CR 300 Minolta}

Pengujian warna pada penelitian ini menggunakan alatChromameter CR 300 Minolta. Data pengukuran dapat berupa nilai absolut maupun nilai selisih dengan standar. Mekanisme kerjanya sebagai berikut, pertama dilakukan kalibrasi terlebih dahulu dengan menekan tombol "CALIBRATE"; Penutup bagian plat kalibrasi sebagai tempat kalibrasi data $\mathrm{x}$ dan y yang akan dimasukkan. Setelah itu, peletakan measuring head pada plat kalibrasi yang berwarna putih, tekan tombol "MEASURE". Kemudian alat chromameter dibiarkan bekerja secara otomatis sejumlah tiga kali hingga pengukuran yang dilakukan selesai. Setelah kalibrasi selesai, pengukuran sampel bisa dilakukan. Pertama measuring head diletakkan pada contoh yang akan diukur, dan tekan tombol "MEASURE", alat akan bekerja dengan sendiri, pengukuran selesai setelah beberapa saat. Pengukuran menghasilkan nilai L, a dan b. L menyatakan parameter kecerahan (warna akromatis, 0: hitam sampai 100: putih). Warna kromatik campuran merah hijau ditunjukkan oleh nilai a $(\mathrm{a}+=0-100$ untuk warna merah, a- =0-(-80) untuk warna hijau. Warna kromatik campuran biru kuning ditunjukkan oleh nilai $b(b+=0-70$ untuk warna kuning, $b-=0-(-70)$ untuk 
warna biru. Pengujian warna dengan tiga kali ulangan dilakukan terhadap mi sagu yang dihasilkan.

\section{Analisis Sensori dengan Uji Kesukaan / RatingHedonik}

Analisis sensori dilakukan dengan empat kriteria mutu yaitu kekerasan, kelengketan, elongasi dan atribut keseluruhan. Mi sagu kering dan mi terigu (gandum) adalah sampel yang digunakan pada tahap ini, sedangkan uji kesukaan/rating hedonik adalah uji yang digunakan. Panelis tidak terlatih dengan jumlah 70 orang sebagai panelis yang digunakan pada tahap ini. 7 skala hedonik digunakan pada tahap penelitian dengan menggunakan urutan skala 1 menyatakan sangat tidak suka, skala 2 menyatakan tidak suka, skala 3 menyatakan agak tidak suka, skala 4 menyatakan netral, skala 5 menyatakan agak suka, skala 6 menyatakan suka, dan skala 7 menyatakan sangat suka. Uji ANOVA digunakan untuk menganalisis data yang didapatkan dengan tujuan untuk mengetahui perbandingan tingkat kesukaan antara mi sagu kering dan mi terigu (gandum). Uji lanjut menggunakan uji Duncan pada taraf nyata 5\% dilakukan apabila hasil dari analisis yang didapatkan berbeda nyata.

\section{HASIL DAN PEMBAHASAN}

\section{Range Variabel Proses Dan Formula}

Tabel 1 menyajikan pengaruh suhu ekstruder dan kadar air (ka) adonan terhadap sifat karakteristik fisik mi pati sagu sebelum dikeringkan (setelah keluar dari ekstruder). Berdasarkan Tabel 1, karakteristik fisik mi dipengaruhi oleh perlakuan suhu ekstruder dan kadar air (ka) adonan. Range suhu ekstruderuntuk proses yang dipilih adalah $65-80^{\circ} \mathrm{C}$ dan kadar air adonan $60 \%$ karena menghasilkan karakteristik fisik mi pati sagu yang tidak mudah putus dan tidak lengket.
Tabel 2 menyajikan pengaruh suhu dan lama pengeringan terhadap karakteristik fisik mi sagu kering. Berdasarkan Tabel 2, karakteristik fisik mi dipengaruhi oleh perlakuan suhu dan lama pengeringan pada alat pengering rak (tray drier). Penggunaan suhu $50^{\circ} \mathrm{C}$ sekitar 3 jam dapat menghasilkan karakteristik fisikyang tidak mudah patah pada mi dibandingkan penggunaan suhu $40^{\circ} \mathrm{C}$ dan $60^{\circ} \mathrm{C}$. Hal tersebut diatas menjadi keputusan untuk menggunakan suhu $50^{\circ} \mathrm{C}$ terhadapmi sagu pada tahapan proses produksi mi sagu kering.

Penentuan kisaran konsentrasi GMS dan ISP dilakukan berdasarkan riset Takahashi et al. (1986) yang melakukan penambahan ISP sebanyak $5 \%$ pada mi berbahan dasar pati kacang hijau dan pati kentang. Hasil penelitian Takahashi et al. (1986) menunjukkan penambahan ISP sebanyak $5 \%$ dapat meningkatkan elongasi, menurunkan kelengketan, dan kelarutan. Berdasarkan studi Kaur et al. (2005) bahwa penurunan cookinglosspada mi pati kentang dan mi pati jagung terjadi karena penambahan GMS sebanyak 1\%. Berdasarkan penelitian tersebut maka range konsentrasi yang digunakan pada tahap ini adalah GMS 0-5\% dan ISP 0-10\%.

\section{Karakterisasi Sifat Kimia, Warna Dan Sensori Mi Sagu Kering}

Karakteristik fisik yang baik dari proses produksi mi sagu kering di analisis secara kimia. Komposisi kimia dari mi sagu kering yang dihasilkan diketahui dengan cara analisis kimia. Analisis warna yang dilakukan terhadap mi sagu kering untuk mengetahui nilai L (kecerahan), a (warna kromatik campuran merah hijau), dan b (warna kromatik campuran biru kuning) adalah dengan notasi Hunter.Uji kesukaan/rating hedonik 70 orang panelis tidak terlatih digunakan sebagai analisis 
Tabel 1.Karakteristik fisik mi pati sagu akibat suhu ekstruder dan kadar air adonan

\begin{tabular}{|c|c|c|}
\hline Suhu $\left({ }^{\circ} \mathrm{C}\right)$ & Kadar air (\%) & Sifat fisik mi pati sagu \\
\hline \multirow{4}{*}{60} & 40 & Lunak, mudah putus \\
\hline & 50 & Lunak, mudah putus \\
\hline & 60 & Lunak, mudah putus \\
\hline & 70 & Tidak diproses ekstrusi karena adonan cair \\
\hline \multirow{4}{*}{65} & 40 & Lunak, mudah putus \\
\hline & 50 & Lunak, mudah putus \\
\hline & 60 & Agak lunak, tidak mudah putus \\
\hline & 70 & Tidak diproses ekstrusi karena adonan cair \\
\hline \multirow{4}{*}{80} & 40 & Keras, lengket \\
\hline & 50 & Agak keras, tidak lengket \\
\hline & 60 & Agak keras, tidak lengket \\
\hline & 70 & Tidak diproses ekstrusi karena adonan cair \\
\hline \multirow{4}{*}{85} & 40 & Sangat keras, lengket \\
\hline & 50 & Keras, lengket \\
\hline & 60 & Keras, lengket \\
\hline & 70 & Tidak diproses ekstrusi karena adonan cair \\
\hline
\end{tabular}

organoleptik terhadap mi sagu kering. Pada uji kesukaan/rating hedonik ini parameter yang diamati adalah kekerasan, kelengketan, elongasi, dan keseluruhan (overall).

\section{Komposisi Kimia dan Warna Mi Sagu Kering}

Suatu produk bahan makanan menjadi salah satu penentu tingkat penerimaan konsumen adalah dengan melihat banyaknya kadar air pada produk tersebut. Hasil analisis proksimat mi sagu kering ditunjukkan pada Tabel 3. Kadar air produk mi sagu kering sebesar $10.32 \%$. Berdasarkan SNI (01-2974-1996), kadar air pada mi kering memiliki persyaratan mutu 1 maksimal 8\% dan maksimal 10\% untuk persyaratan mutu 2.Berdasarkanhasil tersebut maka kadar air dari mi sagu kering belum memenuhi syarat mutu 2 berdasarkan SNI. Namun, menurut SNI 2000 dan SNI 2012 bahwa kadar air mi dengan teknik pengeringan maksimal 14.5\%. Menurut Codex (2006), $14 \%$ adalah maksimum kadar air mi yang tidak digoreng. Hal ini menunjukkan bahwa terpenuhinya syarat persyaratan codex dan SNI 2000 dan SNI 2012 terhadap kadar air mi sagu kering.

Tabel 2. Karakteristik fisik mi sagu kering akibat suhu dan lama pengeringan

\begin{tabular}{ccc}
$\begin{array}{c}\text { Suhu } \\
\left({ }^{\circ} \mathrm{C}\right)\end{array}$ & $\begin{array}{c}\text { Lama pengeringan } \\
\text { (Jam) }\end{array}$ & $\begin{array}{c}\text { Sifat fisik mi } \\
\text { sagu kering }\end{array}$ \\
\hline 40 & 3.50 & $\begin{array}{c}\text { Agak keras, } \\
\text { mudah patah } \\
\text { Agak keras, } \\
\text { tidak mudah } \\
\text { patah } \\
50\end{array}$ \\
60 & 3.00 & $\begin{array}{c}\text { Keras, mudah } \\
\text { patah }\end{array}$ \\
\hline
\end{tabular}

Kadar abu (0.20\%) sebagai kandungan bahan mineral dari suatu produk, kadar lemak $(0.21 \%)$ yang memiliki peranan penting dalam bahan pangan, misalnya 
sebagai penambah cita rasa, memperbaiki tekstur, dan menambah nilai gizi merupakan komponen-komponen yang terdapat pada produk mi sagu kering. Lemak dalam makanan akan menimbulkan rasa kenyang, namun konsumsi lemak yang terlalu banyak akan memberikan perasaan mual (Winarno 1980). Kandungan tertinggi pada produk mi hasil dari penelitian ini adalah karbohidrat sebesar 86.63\%. Kandungan karbohidrat, lemak, dan protein pada proses produksi mi sagu dengan penambahan ISP dan GMS lebih tinggi dibandingkan penelitian yang dilakukan oleh Novanto dan Zainal (1989), yang menyatakan bahwa sagu memiliki kandungan karbohidrat $85.9 \%$, lemak $0.2 \%$, dan protein $1.4 \%$.

Berdasarkan analisis warna notasi Hunter ( $\mathrm{L}, \mathrm{a}, \mathrm{b})$ dengan menggunakan alatchromameter mi sagu kering pada suhu $80^{\circ} \mathrm{C}$ dengan penambahan GMS $4.5 \%$ dan ISP 3.7\% mempunyai nilai L (34.70), a (2.56), dan b (6.19) yang menunjukkan mi sagu kering memiliki warna abu-abu.

Tabel 1Komposisi kimia (\%bk) dan warnami sagu kering hasil proses optimum

\begin{tabular}{lc}
\multicolumn{1}{c}{ Komponen } & Nilai \\
\hline Air & $10.32 \pm 0.39$ \\
Abu & $0.20 \pm 0.01$ \\
Protein & $2.63 \pm 0.10$ \\
Lemak & $0.21 \pm 0.01$ \\
Karbohidrat & $86.63 \pm 0.50$ \\
Warna : & \\
$\quad$ L & 34.70 \\
a & 2.56 \\
b & 6.19 \\
\hline
\end{tabular}

\section{Analisis Sensori Mi Sagu Kering}

Mi sagu kering dan mi terigu yang dibandingkan dengan perbandingan ratarata skor organoleptik ditunjukkan pada Tabel 4. Hasil uji t-test menunjukkan bahwa tidak terdapat perbedaan signifikan antara mi sagu kering dan mi terigu pada parameter kekerasan, kelengketan, elongasi dan overall. Hal ini berarti tingkat kesukaan/hedonik panelis pada hasil penelitian mi yang berbahan sagu (mi sagu kering) dan terigu (mi terigu) adalah sama.

Tabel2 Perbandingan rata-rataskor organoleptik antara mi sagu kering dan mi terigu $(n=70)$

\begin{tabular}{lcc}
\hline \multirow{2}{*}{ Parameter } & \multicolumn{2}{c}{ Rata-rata skor* } \\
\cline { 2 - 3 } & Mi sagu kering & Mi terigu \\
\hline Kekerasan & 4.3 & 4.4 \\
Kelengketan & 4.0 & 4.0 \\
Elongasi & 4.2 & 3.7 \\
Overall & 4.0 & 4.1 \\
\hline
\end{tabular}

*keterangan: 1 = sangat tidak suka, $2=$ tidak suka, $3=$ agak tidak suka, $4=$ netral, $5=$ agak suka, $6=$ suka, $7=$ sangat suka

\section{KESIMPULAN}

Komposisi kimia dan warna pada mi sagu kering adalah air (10.32\%), abu $(0.20 \%)$, protein $(2.63 \%)$, lemak $(0.21 \%)$, karbohidrat (86.63\%), dan nilai warna (L $=34.70, \mathrm{a}=2.56, \mathrm{~b}=6.19$ ). Hasil skor sensori antara produk mi terigu dan produk mi sagu kering menunjukkan tidak berbeda nyata terhadap atribut kekerasan, kelengketan, elongasi, dan keseluruhan (overall).

\section{DAFTAR PUSTAKA}

Bintoro MH. 2016. Seminar Ilmiah dan Lokakarya Nasional "Sagu". http://www.beritasatu.com/industri -perdagangan/398288-jadikan-sagusebagai-pangan-strategis.html

[BSN] Badan Standardisasi Nasional. 1992. SNI 01-2891-1992. Cara uji makanan dan minuman. Jakarta : Pusat Standarisasi Industri, Departemen Industri.

[BSN] Badan Standardisasi Nasional. 1996. SNI 07-2974-1996. Mi kering. Badan Standardisasi Nasional. Jakarta.

[BSN] Badan Standardisasi Nasional. 2000. SNI 01-3551-2000. Syarat mutu mi 
instan. Badan Standardisasi Nasional. Jakarta.

[BSN] Badan Standardisasi Nasional. 2012. SNI 04-3551-2012. Syarat mutu mi dengan proses pengeringan. Badan Standardisasi Nasional. Jakarta.

Budijanto S, Yuliyanti. 2012. Studi persiapan tepung sorgum (Sorghum bicolor L. Moench) dan aplikasinya pada pembuatan beras analog. $J$ Teknol Pertanian 13(3):177-186.

[CAC] Codex Alimentarius Commission. 2006. Codex Standard for Instant Noodles: Codex Stan 249-2006. FAO United Nations, London.

[DITJENBUN KEMENTAN] Direktorat Jenderal Perkebunan Kementerian Pertanian. 2013. Peningkatan produksi, produktivitas dan mutu tanaman tahunan tentang pedoman teknis pengembangan tanaman sagu. Jakarta.

Kaur L, Singh J, Singh N. 2005. Effect of glycerol monostearate on the physicochemical, thermal, rheological and noodle making properties of corn and potato starches. Food Hydrocoll 19:839-849.

Marti A, Pagani MA, Seethraman K. 2011. Understanding starch organization in gluten-free pasta from rice flour. Carbpol 84: 1069-1074.

Mohamed A, Jamilah B, Abbas KA, Abdul Rahman R, Roselina K. 2008. A review on physicochemical and thermorheological properties of sago starch. Am. J. Agri. \& Biol. Sci 3(4): 639-646.

Novarianto H dan Zainal M. 1989. Sagu Pendamping Beras Di Masa Depan. Buletin Balitka No 7. Departemen Pertanian. Badan Penelitian dan Pengembangan Pertanian. Menado.

Ruku S. 2009. Meningkatkan minat masyarakat mengolah sagu untuk berbagai produk olahan. Sulawesi Tenggara. Buletin Teknologi dan Informasi, Balai Pengkajian
Teknologi Pertanian Sulawesi Tenggara.

Subarna, Muhandri T, Nurtama B, firlieyanti AS. 2012. Peningkatan mutu mi kering jagung dengan penerapan kondisi optimum proses dan penambahan Monogliserida. J Teknol Indust Pangan 23:2.

Syakir M, Karmawati E. 2013. Potensi tanaman sagu (metroxylon spp) sebagai bahan baku bioenergi. Perspektif 12(2):57-64.

Takahashi S, Hirao K, Watanabe T. 1986. Effect of added soybean protein on physico-chemical properties of starch noodles (harusame). J Japan Soc Starch Sci (Depun Kagaku) 33(1):15-24.

Tan HZ, Li ZG, Tan B. 2009. Starch noodles: History, classification, materials, processing, structure, nutrition, quality evaluating and improving. $J$ Food Res Int 42:551-576.

Winarno FG 1980. Kimia pangan. Food Technology Development Center, IPB. Bogor. 